\title{
Corporate Governance Mechanisms and Extent of Disclosure: Evidence from Listed Companies in Malaysia
}

\author{
Wan Izyani Adilah Wan Mohamad \\ Faculty of Business Management and Accountancy \\ Universiti Sultan Zainal Abidin \\ Gong Badak Campus, Terengganu, Malaysia \\ Tel: 60-9-665-3767 E-mail: izyaniadilah@udm.edu.my \\ Zunaidah Sulong (Corresponding author) \\ Faculty of Business Management and Accountancy \\ Universiti Sultan Zainal Abidin \\ Gong Badak Campus, Terengganu, Malaysia \\ Tel: 60-9-665-3750Ｅ-mail: zunaidah@udm.edu.my \\ The research is financed by Universiti Sultan Zainal Abidin Research Grant No. UDM/09/BR(0015)
}

\begin{abstract}
The purpose of this study is to examine the relationship between corporate governance mechanisms and extent of disclosure for listed companies in Malaysia. The study attempts to address two research issues: (1) level of corporate governance disclosure by listed companies in Malaysia; and (2) to what extent corporate governance mechanisms affect company disclosure. Regression analysis is conducted to determine the association between corporate governance mechanisms and the extent of disclosure level in Malaysian corporate sector practices. The evidence supports the conjecture that companies with higher percentage of family members sit on the board are significantly have lower level of disclosure in their annual reports.
\end{abstract}

Keywords: Corporate governance disclosure, Governance mechanisms, Transparency, Financial reporting

\section{Introduction}

Weakness in corporate governance and lack of transparency are considered causes of the Asian financial crisis, and the subsequent events of corporate collapses and accounting fraud. As a consequence, investors have demanded improvements in governance practices which lead to the implementation of corporate governance codes as the guidelines for companies to improve their governance and disclosure practices. The issue arises as to whether these improvements have been effective in reducing agency costs and therefore enhancing company disclosure. According to Abdul Hadi et al. (undated), financial transparency is an important mechanism that provides depositors, creditors and shareholders with the credible assurances that they will not do fraudulent activities. Therefore, the audited financial statements comprise a crucial part of the financial reporting system that is required for effective corporate governance. Further, Beasley et al. (2000) have suggested the need for auditors to acknowledge weak governance mechanisms that are related to financial fraud across a number of time periods and industries.

It is generally known that disclosure is one of the fundamental goals of financial reporting system as it becomes a tenet of any corporate governance system. As highlighted by Melis (2004), a good system of corporate governance requires a good level of disclosure and adequate information to reduce information asymmetries between all parties and making corporate insiders accountable for their action. The financial reporting system represents the main mechanism to provide adequate information to shareholders. As such, financial reporting and disclosure can limit the top management's discretion to pursue their own interest.

Recognising the importance of corporate governance mechanisms and disclosure adequacy, it is significant to have a study focusing on the level of corporate governance disclosure practices among Malaysian companies. Hence, this study attempts to find out whether the established corporate governance mechanisms; namely the proportion of independent non-executive directors, the proportion of independent members of audit committee, the practice of separate CEO and chairman of the board, and the percentage of family members on the board have significant relationships with level of disclosure, particularly in one of emerging market such as Malaysia.

The remainder of this paper is structured as follows. The next section discusses related prior studies and hypotheses development. The following section explains methodology. Data analysis section provides discussion of the findings. Final section concludes the paper. 


\section{Review of Literature}

\subsection{Differences on the extent of corporate governance disclosure}

Many prior studies have provided evidence that company size is positively associated with disclosure levels (see for instance, Meek et al. 1995; Bujaki \& McConomy 2002; Ahmed \& Courties 1999; Tan et al. 1990). According to Bujaki and McConomy (2002), large companies should not generally have difficulty to satisfy the governance requirements compared to smaller companies; even smaller companies may choose to adopt a system of governance which materially departs from the requirements. Therefore, it is expected that the extent of disclosure by large companies will be higher than small companies. The following hypothesis is proposed:

$\mathrm{H}_{1}$ : The extent of corporate governance disclosure in large companies is higher than small companies.

\subsection{The proportion of independent non-executive directors on board}

Board of directors' key role is to monitor management decisions. There are two types of directors on the board, namely executive and non-executive. Executive directors have direct responsibility in managing the business such as finance and marketing since they are full-time employees of the company (Weir \& Laing 2001). Meanwhile, non-executive directors (NEDs) are needed to provide independent judgment such as pay awards, executive director appointments and dismissals when dealing with the executive directors. As such, to have an effective control of management, the board of directors must be independent, in other words, mainly consists of non-executive directors.

Chen and Jaggi (2000) find that a positive association between the ratio of independence NEDs and the comprehensive of financial disclosure support this result. Their result provides evidence suggesting that the proportion of independent NEDs on board is an effective monitor. Besides, the agency theory also suggests a greater proportion of independent NEDs in order to monitor any self-interested actions by executive directors and to minimise the agency cost. Therefore, non-executive directors are seen as a mechanism for monitoring and controlling the actions of the managers and protecting the shareholders interests as well. The larger the proportion of independent non-executive directors on the board, the more effective it will be in monitoring managerial opportunism.

Thus, it is expected that having independent NEDs on the board will also result in higher disclosure (for example, Fama \& Jensen 1983; Chen \& Jaggi 2000; Bujaki \& McConomy 2002; Forker 1992). As such, the following hypothesis is stated as:

$\mathrm{H}_{2}$ : The proportion of independent NEDs has a positive relationship with the level of disclosures.

\subsection{The proportion of independent non-executive directors in audit committee}

The main duty of audit committee is to meet the external auditors regularly to review financial statements, audit processes and internal accounting system and control. Therefore, the establishment of the audit committee will ensure that there is continuous communication between the board and external auditors (Rashidah \&Fairuzana 2006).

In Malaysia, Bursa Malaysia listing requirements mandate every listed company to establish an audit committee consisting of at least three directors of whom a majority is independent (Note 1), while its chairman should be an independent NED (Note 2). In other words, independence of audit committee is based on proportion of independent NEDs in the committee. This independent audit committee will increase the effectiveness and efficiency of the board in monitoring the financial reporting process of a company.

Ho and Wong (2001) provide evidence to support the relationship between the existence of audit committee and the level of disclosure. They find a significant and positive relationship between the existence of audit committee and the extent of voluntary disclosure. Similarly, a study by Barako et al. (2006) also provides strong support whereby they find a significantly positive relationship between the presence of audit committee and voluntary disclosure in Kenyan companies.

According to the agency theory, the independent members in audit committee can help the principals to monitor the agents' activities and reduce benefits from withholding information. As a result, the independent NEDs in the audit committee help to increase the level of disclosure by the listed companies. It is therefore hypothesised that:

$\mathrm{H}_{3}$ : The proportion of independent NEDs in the audit committee has a positive relationship with the level of disclosures.

\subsection{The practice of separate CEO and chairman of the board}

Dominant personality or role duality refers to the CEO who is also the chairman of the board. In other words, a 
person has two powerful positions on the board, which would result in probability that person withholds unfavorable information to outsiders. It is because a chairman has a responsibility to monitor the directors on the board as well as the CEO. Besides, it also enables the CEO to engage in opportunistic behavior since he/she has dominance over the board. When CEO duality exists, the CEO needs to monitor both its own decisions and actions, thus actions in the best interest of the shareholders may not be performed.

In the case of disclosure, Ho and Wong (2001) report that there is no significant relationship between dominant personalities and level of disclosure by Hong Kong listed companies. In contrast, Gul and Leung (2004) observe a negative relationship between companies in Hong Kong with CEO duality (defined as CEOs who jointly serve as board chairs) and level of voluntary disclosure.

In Malaysia, there are no mandatory rules for the separation of roles between both chairman and CEO. The adoption is recommended in the Malaysian Code to separate the roles of chairman and CEO. A company which combines the roles of chairman and CEO should have a strong independent element on the board and should be publicly explained (Note 3). In corporate governance system, it might be expected that independent chairman would lead to a more transparent board and hence to greater disclosure. Based on the discussion above, the following hypothesis is developed:

$\mathrm{H}_{4}$ : The practice of separate CEO and chairman has a positive relationship with the level of disclosures.

\subsection{The percentage of family members on the board}

According to Nicholls and Ahmed (1995), in companies where families have substantial equity holdings, there is generally little physical separation between owners and managers of capital. Thus, the capital owners may not demand highly on disclosure in order to monitor their investments due to better access to internal information. As such, demand for public disclosure will be lower for family controlled companies compared to non-family controlled companies.

A number of empirical evidence supports the relationship between the high percentage of family members on the board and the level of disclosure, for instance, Ho and Wong (2001) find that companies in Hong Kong with a higher proportion of family members on the board are more likely to have lower level of voluntary disclosure. Thus, the result is consistent with prior study by Chen and Jaggi (2000) that the association between independent NEDs and the comprehensive of financial disclosures (i.e. mandatory and voluntary disclosures) is weaker for family controlled firms compared to non-family controlled firms. In the context of Malaysia, many listed companies are family owned or controlled (Rashidah \& Fairuzana 2006), most newly public listed companies have evolved from traditional family owned enterprises (Ow-Yong \& Guan 2000). Therefore, in family controlled companies, the owner-managers may not be fully aware of the importance of having more disclosure transparency in business practices.

Further, Haniffa and Cooke (2002) provide evidence for the Malaysian companies with the proportion of family members on the board have a negative significant relationship with the extent of disclosure. Similarly, Chau and Gray (2002), also find that the family controlled companies are likely to have lower disclosure. They note that the scenario occurs because of the assumption that "insider" or family controlled companies is less motivated to disclose the information since the demand for the information is quite low as the shareholders might get the information by themselves. Hence, it is suggested that:

$\mathrm{H}_{5}$ : The percentage of family members has a negative relationship with the level of disclosures.

\subsection{Differences on the effect of corporate governance mechanisms}

As the background and nature of the main board and second board companies are different, the results of examining $\mathrm{H}_{2}-\mathrm{H}_{5}$ would also be expected to be different between large and small companies. Therefore, it leads to the following hypothesis:

$\mathrm{H}_{6}$ : The effect of corporate governance mechanisms on corporate governance disclosure is different between large and small companies.

\section{Methodology}

\subsection{Sample selection and data}

This study is conducted after the implementation of the Malaysian Code of Corporate Governance (MCCG) through the amendments of Bursa Malaysia Listing Requirements, announced in January 2001. Since then, it is documented that with various best practices and recommendations, the listed companies in Malaysia have improved their corporate governance environment (KLSE-PricewaterhouseCoopers 2002; Roszaini \& Mohammad 2006; Puan et al. 2006). Therefore, the sample years 2002 and 2006 are chosen to represent two 
years of the MCCG becoming mandatory through a revamp of Bursa Malaysia listing requirements. It is expected that these companies already aware and improve their corporate governance disclosure in line with the most recent rules and regulations and the best practices of corporate governance.

This study focuses on the four largest industry sectors of listed companies in the Main and Second Board of Bursa Malaysia (Note 4). These four sectors are consumer, industrial, construction, and trading/service sectors. All companies in each sector are ranked in descending order based on the market capitalisation. Then, for each sector, 10 companies will be chosen randomly. Finally, a total of 40 companies out of the total population are selected. A minimum sample size of 30 is appropriate for most research (Sekaran 2003). Table 1 provides details on the selection of companies. The same procedure is applied for both years 2002 and 2006 with a total of 80 companies out of the total population are chosen.

A final sample selection of 160 companies will be examined in this study. Although the companies selected for this present study only represents 9.3\% (2006-Main Board), 16.9\% (2006-Second Board), 13.2\% (2002-Main Board) and $16.9 \%$ (2002-Main Board) of total number of companies, their market capitalisation represents $21 \%$, $25 \%, 25 \%$, and $24 \%$, respectively. These statistics indicate the importance and significance contribution of these companies in the Malaysian market.

The stratified random sample selection is chosen in order to have general representative sample from a significant proportion of the listed companies, with regard to the extent of corporate governance disclosure. Therefore, the results obtained are able to be generalised to Malaysian listed companies in the respective industrial sectors. Table 2 represents list of companies used in the sample study for the financial year ended 2002 and 2006.

Data are sourced from individual company annual reports. These annual reports are available and downloadable from the website of Bursa Malaysia (http://announcements.bursamalaysia.com). However, four annual reports are not available in the website, where each of two annual reports from the second board companies in the year 2002 and 2006. Therefore, those four companies are dropped from the sample companies in this study.

\subsection{Description of variables}

\subsubsection{Dependent variable}

The dependent variable used in this study is the disclosure index as a proxy for corporate governance disclosure. This measure has been used extensively by prior studies (see, Ho \& Wong 2001; Chau \& Gray 2002; Bujaki \& McConomy 2002; Chen \& Jaggi; 2002; Eng \& Mak 2003; Gul \& Leung 2004; Haniffa \& Cooke 2005; Barako et al. 2006). The index is developed with the expectation that compliance to the best practices of corporate governance will provide incentive for companies to disclose information on corporate governance.

Disclosure score is developed based on the best practice of corporate governance in MCCG and Bursa Malaysia Listing Requirements. There are 40 disclosure items where all the items are coded " 1 " if the companies disclose and coded " 0 " if not, except for one item which has a maximum score of 2 (refer to Table 3). Finally, all the disclosure scores are added to get a total score for each company whereby the maximum disclosure score is 41 .

\subsubsection{Independent variables}

Four independent variables are examined in this study to represent corporate governance mechanism variables. The four measures are as follows:

(i) Independent non-executive directors (INED): The proportion of independent non-executive directors to total number of directors is the number of independent non-executive directors divided by the total number of directors on the board.

(ii) Audit committee (AUDITCOM): The proportion of independent non-executive directors to total number of committees is the number of independent non-executive directors in the audit committee divided by the total number of directors in the audit committee.

(iii) Separate CEO and chairman (SEP_CEO): The variable is coded '1' if there is separated CEO and chairman of the board of directors, ' 0 ' if combined CEO and Chairman.

(iv) Family members on the board (FMEMBER): The percentage of family members on the board to a total number of directors is the number of family members sit on the board divided by the total number of directors on the board. Bursa Malaysia Listing Requirements mandate that every listed companies to disclose the relationship or related board members in the annual report. Based on information available in the annual report, the researcher could easily identify companies with family relationship or related. Usually, such information can be found in director's profile section. 


\subsubsection{Control variables}

The control variables are measured as follows: (i) firm size (SIZE) is measured by total asset;

leverage (LEV) is measured by total debt over equity value of the firm; (iii) profitability (PROFIT) is measured by the return on sales; and (iv) financial year (YEAR) is awarded 0 for year 2002 and 1 for year 2006.

\subsection{The empirical model}

The empirical model equation used in this study is depicted as:

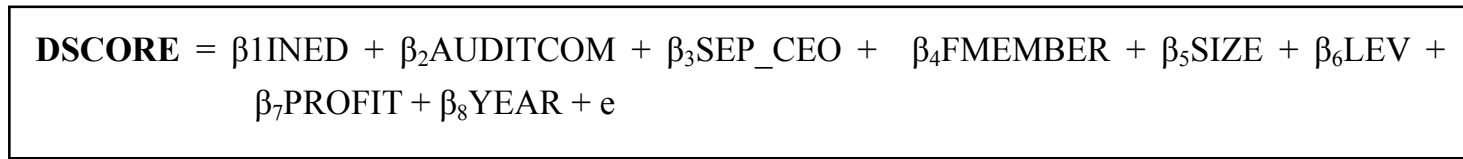

Where;

DSCORE $=$ Disclosure score (in percentage).

INED $=$ Proportion of independent non-executive directors on the board.

AUDITCOM $=$ Proportion of independent members of audit committee.

SEP_CEO $=$ Whether roles of Chairman and CEO are combined or separated. 0 if the CEO is also Chairman of the board of directors, 1 otherwise.

FMEMBER $=$ Percentage of family members on the board.

SIZE $\quad=$ Total asset.

LEV $\quad=$ Total debt over equity value of the firm.

PROFIT $=$ Return on sales.

YEAR $=$ Financial year where 0 for year 2002 and 1 for year 2006

e $\quad=$ Error term

\section{Data Analysis}

\subsection{Descriptive analysis}

Table 4 provides the descriptive statistics for all variables utilised in this study. The table reports the mean, maximum, minimum, standard deviation, skewness, and kurtosis. Based on Table 4, results of skewness and kurtosis show that many of the situations are not in the range of -1.0 and +1.0. Skewness and kurtosis are greater than 1.0 or less than -1.0 indicates a non-symmetrical distribution (Vaus 2002). As such, the normality assumption is rejected. Therefore, the researcher decides to transform variables in order to normalize the data by deleting outliers for leverage and profitability variables only. It is because the findings show that only both variables are highly skewed whilst the remaining variables are within or not very much away from the acceptable range.

\subsection{Correlation analysis}

Table 5 reports Pearson correlation analysis for all companies in the sample. Correlation analysis is used as a preliminary test to measure the relationship between the variables and their strength of the association (Pallant 2001). The low intercorrelation among the explanatory variables used in the regression indicates no reason to suspect serious multicollinearity (Note 5).

\subsection{Univariate analysis}

As mentioned earlier, the normality assumption is rejected. Therefore, non-parametric statistics that is Mann-Whitney U-test is conducted in the univariate analysis. This non-parametric test for two independent samples is useful to determine whether the value of particular variable differs between two groups, i.e. large and small companies, for years 2002 and 2006. The advantage of Mann-Whitney U-test over the independent-samples t-test is that Mann-Whitney does not assume normality. In this study, Mann-Whitney U-test is conducted to test $H_{1}$ : The extent of corporate governance disclosure in large companies is higher than small companies. Results of the non-parametric Mann-Whitney U-test for all samples, years 2006 and year 2002 are shown in the Table 6.

The result reveals that year 2006 has higher mean rank of disclosure score (DSCORE) compared to year 2002. Mann-Whitney U-test shows that there is statistically significant difference at 0.01 level between the mean for the year 2002 and 2006. The DSCORE gives a Z score of $-3.018(p<0.01)$. Thus, this result suggests that 
companies in the year 2006 disclose more information about corporate governance in their annual reports.

Meanwhile, results from Table 6 also comparing the values of DSCORE among the year 2006 and 2002 for large and small companies. The binary method is used to differentiate between the listed board companies, where large companies are coded as 0 and small companies are coded as 1 . The results show that the mean rank of DSCORE for large companies is higher than small companies. The finding is applicable to both sample years; however, sample companies in year 2006 only have significant difference in disclosure score compared to the year 2002. As such, it shows that large companies of year 2006 only have been statistically proven having higher level of disclosure compared to small in year 2006. The $\mathrm{Z}$ score is -2.963 (with $p<0.01$ ). It implies that large companies disclose more governance information in year 2006 compared to small companies.

Therefore, $H_{l}$ is supported in this study for year 2006. At the time of data compilation for this study, main board is used to proxy for large company and second board for small company. The expectation of large companies disclose higher than small companies is consistent with the prior findings of Meek et al. (1995), Ahmed and Courties (1999), as well as Eng and Mak (2003). In addition, Bujaki and McConomy (2002) also provide evidence that large companies are more fully implement the corporate governance requirements compared to the smaller companies.

\subsection{Multivariate analysis}

Table 7 presents the relationships between the extent of disclosure (DSCORE) and corporate governance variables for all samples lies in the years 2006 and 2002. The result shows that only one independent variable is statistically significant, which is FMEMBER $(p<0.01)$. The negative relationship between the level of disclosure and percentage of family members sit on the board confirms the $H_{5}$, while the other hypotheses are not supported. The finding is consistent with Ho and Wong's (2001) study and other prior studies (for example, Chen \& Jaggi 2000; Chau \& Gray 2002). The finding suggests that family controlled companies are less motivated to disclose information compared to non-family controlled companies because they can have better access to the internal information. Therefore, the owner-managers might not be fully aware on the importance of having more openness and disclosure in business practice.

The adjusted R-square of 0.211 indicates that the eight variables included in the regression are able to explain $21.10 \%$ of the variation in the disclosure score of corporate governance information. Meanwhile, multicollinearity problem between the variables is weak as the tolerance is not 0.2 or less and VIF is not 5 or more (Vaus 2002). Variance inflation factor (VIFs) scores also reveal no problems with multicollinearity if all scores are less than 10 (Chatterjee \& Price 1991).

Overall, the findings show that only one corporate governance mechanism has a significant impact on the level of disclosure by companies, which is the percentage of family members sit on the board. Table 8 provides the summary of hypotheses and the findings of the study.

\section{Discussion and Conclusion}

The present study extends the work of Ho and Wong (2001) where their study is conducted among listed companies in Hong Kong. The present study is conducted to determine whether their results can be generalised in the Malaysian context. The main objective of this study is to investigate whether the existence of corporate governance mechanisms is effective in increasing the extent of disclosure amongst public listed companies in Malaysia. Four established corporate governance mechanisms are examined in this study, that include (i) the proportion of independent non-executive directors (INED), (ii) the proportion of independent members of audit committee (AUDITCOM), (iii) the practice of separate CEO and chairman of the board (SEP_CEO), and (iv) the percentage of family members on the board (FMEMBER). The individual companies' annual reports for the years 2002 and 2006 have been used as disclosure reference to examine the extent of corporate governance disclosure provided by large and small companies. The comparison between Ho and Wong's (2001) study and current study on the relationship between corporate governance mechanisms and the extent of disclosure is presented in the Table 9.

In conclusion, result from this study reveals that companies with a higher percentage of family members sit on the board are significantly have lower level of disclosure in their annual reports. Therefore, it can be suggested to the regulators such as Bursa Malaysia and Securities Commission to review and impose a certain level of family members sit on the board as proposed by Wallace (2004). Malaysian regulators might implement the same guidelines from Hong Kong Society of Accountant (HKSA) to have a limitation of not more than 50 percent of family members sit on the board. In addition, another additional regulation should also be imposed is not allowing any family members to hold the two top positions in the board that are CEO and chairman of the board. 


\section{References}

Abdul Hadi, Z., M. Fazilah, A.S. \& Md. Ishak, I. (undated). Corporate governance in Malaysia. www.micg.net (Date retrieved: 2/7/2007).

Ahmed, K. \& Courtis, J.K. (1999). Association between corporate characteristics and disclosure levels in annual reports: A meta-analysis. British Accounting Review, 31, 35 - 61.

Barako, D.G., Hancock, P. \& Izan, H.Y. (2006). Factors influencing voluntary corporate disclosure by Kenyan companies. Corporate Governance, 14 (2), 107 - 125.

Beasley, M.S., Carcello, J.V., Hermanson, D.R. \& Lapides, P.D. (2000). Fraudulent financial reporting: Consideration of industry traits and corporate governance mechanisms. Accounting Horizons, 14 (4), 441 - 454.

Bujaki, M. \& McConomy, B.J. (2002). Corporate governance: Factors influencing voluntary disclosure by publicly traded Canadian firms. Canadian Accounting Perspectives, 1 (2), $105-139$.

Chatterjee, S. \& Price, B. (1991). Regression analysis by example. New York: Wiley.

Chau, G.K. \& Gray, S.J. (2002). Ownership structure and corporate voluntary disclosure in Hong Kong and Singapore. The International Journal of Accounting, 37, $247-265$.

Chen, C.J.P. \& Jaggi, B. (2000). Association between independent non-executive directors, family control and financial disclosures in Hong Kong. Journal of Accounting and Public Policy, 19, 285 - 310.

Eng, L.L. \& Mak, Y.T. (2003). Corporate governance and voluntary disclosure. Journal of Accounting and Public Policy, 22, 325 - 345.

Fama, E.F. \& Jensen, M. (1983). Separation of ownership and control. Journal of Law and Economics, 27, 301 325.

Finance Committee on Corporate Governance. (2001). Malaysian Code on Corporate Governance. Kuala Lumpur. Malayan Law Journal Sdn Bhd.

Forker, J.J. (1992). Corporate governance and disclosure quality. Accounting and Business Research, 22 (86), $111-124$.

Gul, F.A. \& Leung, S. (2004). Board leadership, outside directors' expertise and voluntary corporate disclosures. Journal of Accounting and Public Policy, 23, 351 - 379.

Haniffa, R.M. \& Cooke, T.E. (2002). Culture, corporate governance and disclosure in Malaysian corporations. Abacus, 38 (3), 317 - 349.

Haniffa, R.M. \& Cooke, T.E. (2005). The impact of culture and governance on corporate social reporting. Journal of Accounting and Public Policy, 24, 391 - 430.

Ho, S.S.M. \& Wong, K.S. (2001). A study of the relationship between corporate governance structures and the extent of voluntary disclosure. Journal of International Accounting, Auditing \& Taxation, 10, 139 - 156.

Jensen, M.C. \& Meckling, W.H. (1976). Theory of the firm: Managerial behaviour, agency costs and ownership structure. Journal of Financial Economics, 3, 305 - 360.

KLSE-PricewaterhouseCoopers. (2002). Corporate governance: 2002 survey of public listed companies in Malaysia. Kuala Lumpur Stock Exchange (KLSE).

Kuala Lumpur Stock Exchange (KLSE). (2001). Listing requirements of the Kuala Lumpur stock exchange. Kuala Lumpur Stock Exchange (KLSE).

Meek, G.K., Robert, C.B. \& Gray, S.J. (1995). Factors influencing voluntary annual report disclosures by U.S., U.K. and Continental European multinational corporations. Journal of International Business Studies, 26 (3), $555-572$.

Melis, A. (2004). Financial reporting, corporate communication and governance. Corporate Ownership \& Control, 1 (2), $31-37$.

Nicholls, D. \& Ahmed, K. (1995). Disclosure quality in corporate annual reports of non-financial companies in Bangladesh. Research in Accounting in Emerging Economies, 3, 149 - 170.

Ow-Yong, K. \& Guan, C.K. (2000). Corporate Governance Codes: A comparison between Malaysia and the UK. Corporate Governance, 8 (2), 125 - 132.

Pallant, J. (2001). SPSS survival manual: A step by step guide to data using SPSS for Windows (Version 10 and 
11). Philadelphia: Open University Press.

Puan, Y., Kent, P. \& Clarkson, P. (2006). Governance structures, ethnicity and audit fees of Malaysian listed firms. Managerial Auditing Journal, 21 (7), 757-782.

Rashidah, A.R. \& Fairuzana Haneem, M.A. (2006). Board, audit committee, culture and earnings management: Malaysian evidence. Managerial Auditing Journal , 21 (7), 783 - 804.

Roszaini, H. \& Mohammad, H. (2006). Corporate governance structure and performance of Malaysian listed companies. Journal of Business Finance \& Accounting, 1-29.

Sekaran, U. (2003). Research methods for business: A skill-building approach $\left(4^{\text {th }}\right.$ ed.). Singapore: John Wiley \& Sons.

Tan, L.T., Zainal, A.K. \& Cheong, P.W. (1990). Information needs of users and voluntary disclosure practices of Malaysian listed corporations. The Malaysian Accountant , 2-7.

Vaus, D. (2002). Analyzing social science data. London: SAGE Publication.

Wallace, D.J. (2004). Sarbanes-Oxley sets standard for small companies. Rural Telecommunication: Business Matters, 68 - 73.

Weir, C. \& Laing, D. (2001). Governance structures, director independence and corporate performance in the UK. European Business Review, 13 (2), 86 - 94.

\section{Notes}

Note 1. Rule 15.10, KLSE Listing Requirements (2001).

Note 2. Rule 15.11, KLSE Listing Requirements (2001).

Note 3. Malaysian Code on Corporate Governance, 2001, p.12.

Note 4. The merged Second and Main Board will be known as the Main Market and the Mesdaq Market as the ACE Market, with ACE being an acronym for Access, Certainty, and Efficiency. The changes were implemented on August 3, 2009 (http:www.themalaysianinsider.com, accessed on 11 March 2010).

Note 5. This study considers that multicollinearity problem exists when the correlation exceeded 0.6.

Table 1. Selection of companies

\begin{tabular}{|l|l|l|l|l|}
\hline \multirow{2}{*}{ Selection of companies } & \multicolumn{2}{|c|}{2006} & \multicolumn{2}{|c|}{2002} \\
\cline { 2 - 5 } & Main Board & Second Board & Main Board & Second Board \\
\hline Selected sectors: & & & & \\
- Construction & 44 & 16 & 35 & 13 \\
$\bullet \quad$ Consumer products & 87 & 48 & 58 & 58 \\
$\bullet \quad$ Industrial products & 157 & 128 & 105 & 115 \\
$\bullet \quad$ Trading / Services & 142 & 46 & 106 & 51 \\
\hline Final selection & 40 & 40 & 40 & 40 \\
\hline Percentage representative & $9.3 \%$ & $16.9 \%$ & $13.2 \%$ & $16.9 \%$ \\
\hline Proportion of market capitalisation & $21 \%$ & $25 \%$ & $25 \%$ & $24 \%$ \\
\hline
\end{tabular}


Table 2. Sample of companies

\begin{tabular}{|c|c|c|c|c|}
\hline \multirow[b]{2}{*}{ Sector } & \multicolumn{2}{|c|}{2006} & \multicolumn{2}{|c|}{2002} \\
\hline & Main Board & Second Board & Main Board & Second Board \\
\hline \multirow{10}{*}{ Construction } & YTL & LDAUN & YTL & ZECON \\
\hline & ZELAN & ZECON & RENONG & PLS \\
\hline & MTD & PLS & WCT & BGYEAR \\
\hline & SUNWAY & BGYEAR & PJDEV & GADANG \\
\hline & EKOVEST & MAGNA & GCORP & JETSON \\
\hline & LOH\&LOH & SELOGA & PLB & YCS \\
\hline & PSIPTEK & JETSON & IREKA & HOOVER \\
\hline & BPURI & AVGARDE & HOHUP & SETEGAP \\
\hline & SBCCORP & HOOVER & SUREMAX & FAJAR \\
\hline & SUREMAX & CYGAL & MERGE & AVGARDE \\
\hline \multirow{10}{*}{$\begin{array}{l}\text { Consumer } \\
\text { products }\end{array}$} & BAT & DUNBUSH & BAT & DEWINA \\
\hline & CARLSBG & WANGZNG & ORIENT & POHMAY \\
\hline & GOLDIS & REX & HLIND & YEOAIK \\
\hline & MFLOUR & HWATAI & UNZA & PADINI \\
\hline & GUANCHG & LTKM & DNP & HUATLAI \\
\hline & IQGROUP & TAFI & KENMARK & EG \\
\hline & COCOLND & SHH & APOLLO & PINWEE \\
\hline & YSPSAH & HINGYAP & MAMEE & TECGUAN \\
\hline & MAXBIZ & BASWELL & HABIB & FORMOST \\
\hline & LIIHEN & FFHB & NEXNEWS & TOMISHO \\
\hline \multirow{10}{*}{ Industrial products } & PETGAS & ATLAN & ETGAS & INGRESS \\
\hline & CAMERLN & BSLCORP & APM & MULTICO \\
\hline & KIANJOO & LIMAHSN & DMIB & WEIDA \\
\hline & KINSTEL & WATTA & SUBUR & KOMARK \\
\hline & YILAI & BTM & LEADER & JOTECH \\
\hline & DKCORP & EG & ALCOM & GPA \\
\hline & YECHIU & ABRIC & ANCOM & RAPID \\
\hline & AISB & YOKO & TEKALA & LYSAGHT \\
\hline & LSTEEL & GUNUNG & GOPENG & RALCO \\
\hline & OKA & CNASIA & KIALIM & SKW \\
\hline \multirow{10}{*}{ Trading/ Services } & TENAGA & LIONFIB & TENAGA & PHARMA \\
\hline & TRANMIL & GLOBALC & TANJONG & VADS \\
\hline & МРHB & SAMUDRA & AMWAY & FSBM \\
\hline & SAPCRES & JUAN & NALURI & UNIMECH \\
\hline & MUIIND & AMTEL & MUIIND & CENTURY \\
\hline & EPIC & SEEHUP & PMIND & RHYTHM \\
\hline & UTUSAN & KPSCB & WARISAN & CME \\
\hline & SUIWAH & NEPLINE & KKELLAS & TOCEAN \\
\hline & SEG & STAMCOL & ANTAH & TENCO \\
\hline & IPMUDA & KAIPENG & DKMAT & OCEAN \\
\hline Total & 40 & 40 & 40 & 40 \\
\hline
\end{tabular}


Table 3. Disclosure index (developed based on MCCG and Bursa Malaysia LR)

\begin{tabular}{|c|c|c|c|}
\hline & Disclosure Index Component & Scoring ( 1 if disclosed and 0 if not) & Item No. \\
\hline 1. & $\begin{array}{l}\text { Statement by the BODs on the } \\
\text { compliance with the Code. }\end{array}$ & $\begin{array}{l}\text { If the disclosure explicitly states that the board: } \\
\text { - Coded 1: To fully comply / committed to comply or has applied / complied } \\
\text { with the Code, or } \\
\text { - Coded 2: Has substantially or fully complied with the Code. }\end{array}$ & 1 \\
\hline 2. & Composition of the BODs. & $\begin{array}{l}\text { Coded } 1 \text { if the disclosure states at least } 2 \text { directors or } 1 / 3 \text { rd of the BODs, } \\
\text { whichever is the higher, are independent non-executive directors, if not state the } \\
\text { reason. }\end{array}$ & 2 \\
\hline 3. & $\begin{array}{l}\text { Chairman and Chief Executive } \\
\text { Officer. }\end{array}$ & $\begin{array}{l}\text { Coded } 1 \text { if the disclosure states the roles of Chairman and CEO are separated, if } \\
\text { the decision to combine the roles, it should be publicly explained. }\end{array}$ & 3 \\
\hline 4. & $\begin{array}{l}\text { Statement of directors' } \\
\text { responsibility. }\end{array}$ & $\begin{array}{l}\text { Coded } 1 \text { if the disclosure states an explanation on the director's responsibility } \\
\text { for preparing the annual financial statements, if not state the reason. }\end{array}$ & 4 \\
\hline 5 . & Directors' assessment. & $\begin{array}{l}\text { Coded } 1 \text { if the disclosure indicates that there is a process for assessing the } \\
\text { effectiveness of the board, its committees and individual directors. }\end{array}$ & 5 \\
\hline 6. & Directors' training & $\begin{array}{l}\text { Coded } 1 \text { if the disclosure state: } \\
\text { - In the annual report by BODs whether its directors have attended training } \\
\text { programmes prescribed by the Exchange for the financial year, if not state the } \\
\text { reason for each director. } \\
\text { - Detail of the training programmes. } \\
\text { - Providing an orientation and education programme for new directors to the } \\
\text { board. }\end{array}$ & $\begin{array}{l}7 \\
8 \\
\end{array}$ \\
\hline 7. & $\begin{array}{l}\text { Information to the board: } \\
\text { - Supply of information. } \\
\text { - Access to information. }\end{array}$ & $\begin{array}{l}\text { Coded } 1 \text { if the disclosure indicates that: } \\
\text { - The board of directors has been supplied timely basis with the information in } \\
\text { a form. } \\
\text { - Provide further explanation } \\
\text { - All directors (executive and non-executive) have the same right of access to } \\
\text { information. } \\
\text { - Provide further explanation }\end{array}$ & $\begin{array}{l}9 \\
10 \\
11 \\
12\end{array}$ \\
\hline 8. & Internal control statement: & $\begin{array}{l}\text { Coded } 1 \text { if the disclosure provides a statement about the state of internal control } \\
\text { to safeguard shareholder's investment and the company's assets which covering: } \\
\text { - Financial control } \\
\text {-general information, e.g. budgetary } \\
\text {-provide further explanation } \\
\text { - Operational control } \\
\text {-general information, e.g. organizational structure } \\
\text { - provide further explanation } \\
\text { - Risk management } \\
\text {-general information, e.g. risk, management department } \\
\text { - provide further explanation }\end{array}$ & $\begin{array}{l}13 \\
14 \\
15 \\
16 \\
17 \\
18\end{array}$ \\
\hline 9. & $\begin{array}{l}\text { The existence of an internal audit } \\
\text { function. }\end{array}$ & $\begin{array}{l}\text { Coded } 1 \text { if the disclosure states the existence of an internal audit function or } \\
\text { activity, if not state the reason. }\end{array}$ & 19 \\
\hline 10. & $\begin{array}{l}\text { Nomination committee: } \\
\text { - Existence of the nomination } \\
\text { committee for proposing new } \\
\text { directors and assessing directors } \\
\text { on an on-going basis. } \\
\text { - Composition of the } \\
\text { nomination committee. } \\
\text { - Number of meeting }\end{array}$ & $\begin{array}{l}\text { Coded } 1 \text { if the disclosure indicates: } \\
\text { - The existence of a nomination committee or other committee that has } \\
\text { explicitly responsible for nominating new directors. } \\
\text { - A committee of directors composed exclusively of non-executive directors, a } \\
\text { majority of whom are independent, if not state the reason. } \\
\text { - Number of meeting held. }\end{array}$ & $\begin{array}{l}20 \\
21 \\
22\end{array}$ \\
\hline
\end{tabular}




\begin{tabular}{|c|c|c|c|}
\hline 11. & $\begin{array}{l}\text { Remuneration committee: } \\
\text { - Composition of the } \\
\text { remuneration committee. } \\
\text { - Remuneration procedure. } \\
\text { - Remuneration information. }\end{array}$ & $\begin{array}{l}\text { Coded } 1 \text { if the disclosure states that: } \\
\text { - The remuneration committee consists of wholly or mainly of non-executive } \\
\text { directors, if not state the reason. } \\
\text { - The company has formal and transparent procedure for developing policy on } \\
\text { directors' remuneration package and provides further explanation. } \\
\text { - The remuneration details should be shown in the annual report: } \\
\text { - qualitative information } \\
\text { - quantitative information } \\
\text { - total amount } \\
\text { - break down of each total } \\
\text { - range of remuneration amount }\end{array}$ & $\begin{array}{l}26 \\
27 \\
28\end{array}$ \\
\hline 12. & $\begin{array}{l}\text { Audit committee: } \\
\text { - Composition of the audit } \\
\text { committee. } \\
\text { - Chairman of the audit } \\
\text { committee. } \\
\text { - Have direct communication } \\
\text { channels with internal and } \\
\text { external auditors. } \\
\text { - Has oversight responsibility } \\
\text { for system of internal control. }\end{array}$ & $\begin{array}{l}\text { Coded } 1 \text { if the disclosure states that: } \\
\text { - Audit committee consists of at least } 3 \text { members of whom a majority is } \\
\text { independent, if not state the reason. } \\
\text { - Chairman of the audit committee shall be an independent director, if not } \\
\text { state the reason. } \\
\text { - Have direct access to, or communication channels with internal and external } \\
\text { directors and provide further explanation. } \\
\text { - Has oversight responsibility for the system of internal control and provide } \\
\text { further explanation. }\end{array}$ & 31 \\
\hline 13. & Audit committee meeting. & $\begin{array}{l}\text { Coded } 1 \text { if the disclosure states: } \\
\text { - The number of audit committee meetings held } \\
\text { - Details of attendance of each member, if not state the reason. }\end{array}$ & 33 \\
\hline 14. & $\begin{array}{l}\text { A summary of the activities of } \\
\text { audit committee. }\end{array}$ & $\begin{array}{l}\text { Coded } 1 \text { if the disclosure states in an informative way the details of the activities } \\
\text { of the audit committee. }\end{array}$ & 35 \\
\hline 15. & $\begin{array}{l}\text { Audit committee's term of } \\
\text { reference }\end{array}$ & $\begin{array}{l}\text { Coded } 1 \text { if the disclosure has written term of reference which deals with its } \\
\text { authority and duties. }\end{array}$ & 36 \\
\hline 16. & $\begin{array}{l}\text { Relationship with investors and } \\
\text { shareholders. }\end{array}$ & $\begin{array}{l}\text { Coded } 1 \text { if the disclosure states that: } \\
\text { - Company conducts dialogue to communicate with investors or has formal } \\
\text { communication like AGM and annual report. } \\
\text { - Company has informal communication with investors like participative in } \\
\text { regular meeting (other than AGM and annual report). } \\
\text { - Company's website address. } \\
\text { - Person in charge for any enquiries. }\end{array}$ & $\begin{array}{l}39 \\
40\end{array}$ \\
\hline
\end{tabular}

Table 4. Descriptive statistics of all variables

\begin{tabular}{lllllll}
\hline Variable & Mean & Maximum & Minimum & SD & Skewness & Kurtosis \\
\hline DSCORE & 65.04 & 87.80 & 34.15 & 10.09 & -0.356 & 0.297 \\
INED & 40.70 & 100 & 18.18 & 10.54 & 1.670 & 6.053 \\
AUDITCOM & 70.48 & 100 & 33.33 & 10.71 & 0.900 & 3.890 \\
SEP_CEO & 75.00 & 100 & 0 & 43.44 & -1.166 & -0.649 \\
FMEMBER & 23.15 & 72.73 & 0 & 22.85 & 0.337 & -1.284 \\
LOGSIZE & 8.43 & 10.81 & 7.45 & 0.66 & 1.224 & 1.547 \\
LEV & 1.41 & 29.85 & -8.49 & 2.90 & 6.387 & 61.174 \\
PROFIT & 0.84 & 179.79 & -29.83 & 14.68 & 11.772 & 145.191 \\
\hline
\end{tabular}


Table 5. Pearson correlation analysis

\begin{tabular}{|c|c|c|c|c|c|c|c|c|}
\hline All sample & Dscore & INED & $\begin{array}{c}\text { Audit-co } \\
\mathrm{m}\end{array}$ & Dominant & FMember & Logsize & Lev & Profit \\
\hline Dscore & 1 & 0.113 & 0.145 & 0.115 & $-0.321 * *$ & $0.239^{*}$ & 0.140 & 0.166 \\
\hline INED & & 1 & $0.384 * *$ & -0.126 & -0.115 & 0.173 & $0.276^{* *}$ & -0.003 \\
\hline Auditcom & & & 1 & 0.093 & 0.023 & $0.331 * *$ & 0.130 & 0.110 \\
\hline Sep_CEO & & & & 1 & -0.040 & 0.144 & 0.065 & -0.003 \\
\hline FMember & & & & & 1 & -0.139 & -0.165 & -0.151 \\
\hline Logsize & & & & & & 1 & $0.404 * *$ & $0.236^{*}$ \\
\hline Lev & & & & & & & 1 & -0.161 \\
\hline Profit & & & & & & & & 1 \\
\hline
\end{tabular}

Note: The asterisks ** and * denotes correlation are significant at the 0.01 and 0.05 levels, respectively.

Table 6. Mann-Whitney U-test for all sample companies

\begin{tabular}{|c|c|c|c|c|}
\hline DSCORE & Year/Board & Mean Rank & $\mathbf{Z}$ & Sig. \\
\hline \multirow{3}{*}{ All Sample } & 2002 & 41.58 & & \\
\hline & 2006 & 58.95 & & \\
\hline & $\begin{array}{l}\text { Between } \\
\text { group }\end{array}$ & & -3.018 & 0.003 \\
\hline \multirow{3}{*}{2006} & Large & 30.22 & & \\
\hline & Small & 18.28 & & \\
\hline & $\begin{array}{c}\text { Between } \\
\text { group }\end{array}$ & & -2.963 & 0.003 \\
\hline \multirow{3}{*}{2002} & Large & 27.42 & & \\
\hline & Small & 24.74 & & \\
\hline & $\begin{array}{l}\text { Between } \\
\text { group }\end{array}$ & & -0.644 & 0.519 \\
\hline
\end{tabular}

Table 7. Regression analysis for all companies in the sample

\begin{tabular}{lllll}
\multicolumn{1}{c}{ Variable } & \multicolumn{2}{c}{ Results } & \multicolumn{2}{c}{ Collinearity Diagnostics } \\
& Coefficient & p-value & Tolerance & VIF \\
\hline INED & -0.398 & 0.691 & 0.733 & 1.364 \\
AUDITCOM & 0.370 & 0.713 & 0.744 & 1.344 \\
SEP_CEO & 0.685 & 0.495 & 0.935 & 1.070 \\
FMEMBER & $-3.487^{* * *}$ & 0.001 & 0.903 & 1.107 \\
LOGSIZE & 1.627 & 0.107 & 0.661 & 1.513 \\
LEV & 0.018 & 0.986 & 0.704 & 1.420 \\
PROFIT & 0.380 & 0.705 & 0.820 & 1.220 \\
FINANCIAL YEAR & 3.738 & 0.000 & 0.896 & 1.116 \\
\hline $\mathrm{R}^{2}$ & 0.275 & & & \\
Adjusted R & 0.211 & & & \\
F-statistic & $4.275^{* * *}$ & & & \\
\hline
\end{tabular}

Note: The asterisk $* * *$ represents significant at 1 per cent $(\mathrm{p}<0.01)$ level. 
Table 8 . Summary of hypotheses and the findings

\begin{tabular}{ll}
\multicolumn{1}{c}{ HYPOTHESES } & RESULTS \\
\hline $\mathrm{H}_{1}:$ The extent of corporate governance disclosure in large companies is higher than & Supported (year 2006 only) \\
small companies. & \\
\hline $\mathrm{H}_{2}:$ The proportion of independent NEDs has a positive relationship with the level of & Not supported \\
disclosures. & \\
\hline $\mathrm{H}_{3}:$ The proportion of independent NEDs in the audit committee has a positive & Not supported \\
relationship with the level of disclosures. & \\
\hline $\mathrm{H}_{4}:$ The practice of separate $C E O$ and chairman has a positive relationship with the & Not supported \\
level of disclosures. & \\
\hline $\mathrm{H}_{5}:$ The percentage of family members board has a negative relationship with the & Supported \\
level of disclosures. & \\
\hline $\mathrm{H}_{6}:$ The effect of corporate governance mechanisms on corporate governance & Not supported \\
disclosure is different between large and small companies. & \\
\hline
\end{tabular}

Table 9. Comparison of findings between Ho and Wong's (2001) and current study

\begin{tabular}{lcccc}
\hline Corporate governance variable & $\begin{array}{c}\text { Hypothesis } \\
\text { direction }\end{array}$ & Ho and Wong (2001) & Present study \\
\hline$H_{2}:$ Proportion of independent NED on the board & + & + (Not significant) & - (Not significant) \\
$H_{3}:$ Proportion of independent NED in the audit committee & + & + (Significant) & + (Not significant) \\
$H_{4}:$ Separation of roles between CEO and chairman of the & + & + (Not significant) & + (Not significant) \\
board & & - (Significant) & - (Significant) \\
$H_{5}:$ Percentage of family members on the board & - & - &
\end{tabular}

Description for the above table. 